\author{
A.S. Utebekova* iD , Zh.Kh. Salkhanova \\ Al-Farabi Kazakh National University, Kazakhstan, Almaty \\ *e-mail: aray.utebekova@yahoo.com

\section{THE ORIGINALITY OF THE AUTHOR'S CHRONOTOPE IN ESSAY WRITING OF KAZAKH RUSSIAN-SPEAKING WRITERS}

The article deals with the essayism of Kazakh Russian-speaking writers. The authors note that the essay is one of the most productive genres in the expression of philosophical thought, that is, knowledge about the most common aspects of the world and man. The structure-forming principle of the essay is the leading role of the author's personality. Another, no less important feature of the style of the essay is the presence of imagery, expressiveness - that is, the expression of artistry and journalism. Another feature of the essay genre is myth - making. The writer builds his own theories, creating a kind of myth, which is based on imaginary forms. In this regard, according to the authors of this article, the question arises about the spatial and temporal boundaries of the work, the specifics of the author's chronotope.

The purpose of the article is to try to reveal the originality of the author's chronotope in the works of A. Zhaksylykov and B. Kairbekov. The article analyzes the features of the chronotope, the characteristic features of its narrative structure. The authors of the article note that the artistic chronotope is a complex sign system, consisting of several levels and carrying certain information, which is revealed through codes and lexicodes.

As a result of the analysis, the authors formulate conclusions that in the essayistics of Kazakh Russian-speaking writers, the category of artistic chronotope is a "set of pluralities". Its content combines universal, national, collective, and private concepts and theories of time-space. The authors of the article claim that B. Kairbekov's essayism traces the clearly expressed ethno-cultural nature of images and motives. Key concepts and lexicodes of the works of A. Zhaksylykov reflect the everyday life of the East, being the most significant components of space and time.

Key words: essay, chronotope, myth-making, expressiveness, concept.

\author{
А.С. Утебекова*, Ж.Х. Салханова \\ Ә^-Фараби атындағы Қазақ ұлттық университеті, Қазақстан, Алматы қ. \\ *e-mail: aray.utebekova@yahoo.com

\section{Қазақстандық орыс тілді жазушылардың очеркіндегі} \\ авторлық хронотоптың өзіндік ерекшелігі
}

Мақалада қазақстандық орыс тілді жазушылардың эссеистикасы қарастырылады. Авторлар эссе философиялық ойды, яғни әлем мен аАамның ең жалпы жақтары туралы білімді білдірудегі ең өнімді жанрлардың бірі екенін айтады. Эссенің құрылымдық принципі - шығарма авторы тұлғасының жетекші рөлі. Эссе стилистикасының тағы бір маңызды ерекшелігі - бейнелеу, экспрессивтілік - көркемдік пен публицистикалық көрінісі. Эссе жанрының тағы бір ерекшелігі - миф жасау. Жазушы өз теорияларын құрып, өзіндік миф жасайды және оның негізінде қиял бейнелері бар. Осыған байланысты, осы мақаяа авторларының пікірінше, шығарманың кеңістікуақыт шекаралары, авторлық хронотоптың ерекшелігі туралы мәселе туындайды.

Мақаланың мақсаты - А. Жақсылықов пен Б. Қайырбековтің шығармаларындағы авторлық, хронотоптың ерекшелігін анықтау. Мақалада хронотоптың ерекшеліктері, оның баяндау құрылымының сипаттамалары талданады. Мақала авторлары көркем хронотоп бірнеше Аеңгейден тұратын және кодтар мен лексикодтар арқылы ашылатын белгілі бір ақпаратты қамтитын күрделі белгі жүйесі екенін айтады.

Та^дау нәтижесінде авторлар қазақстандық орыс тілді жазушылардың эссеистикасында көркем хронотоп категориясы "көптік жалғаулар жиынтығы" деген тұжырым жасайды. Оның мазмұны жалпыадамзаттық, ұлттық, ұжымдық, жеке ұғымдар мен уақыт-кеңістік теорияларын біріктіреді. Мақала авторлары Б. Қайырбековтің эссеистикасында образдар мен мотивтердің айқын этномәдени сипаты байқалады деп мәлімдейді. А. Жақсылықовтың шығармаларының негізгі тұжырымдамалары мен лексикодтары кеңістік пен уақыттың едәуір маңызды компоненттері бола отырып, Шығыстың тұрмыстық жағдайын көрсетеді.

Түйін сөздер: эссе, хронотоп, миф жасау, экспрессивтілік, тұжырымдама. 


\author{
А.С. Утебекова*, Ж.Х. Салханова \\ Казахский национальный университет имени аль-Фараби, Казахстан, г. Алматы, \\ *e-mail: aray.utebekova@yahoo.com \\ Своеобразие авторского хронотопа \\ в эссеистике казахстанских русскоязычных писателей
}

\begin{abstract}
В статье рассматривается эссеистика казахстанских русскоязычных писателей. Авторы отмечают, что эссе является одним из наиболее продуктивных жанров в выражении философской мысли, то есть знания о наиболее общих сторонах мира и человека. Структурообразующим принципом эссе является ведущая роль кичности автора произведения. Аругая, не менее важная черта стилистики эссе - наличие образности, экспрессивности, т.е. того, что яв яется выражением художественности и публицистичности. Еще одна особенность жанра эссе мифотворчество. Писатель строит собственные теории, создавая своеобразный миф, в основе которого - воображаемые образы. В этой связи, по мнению авторов Аанной статьи, возникает вопрос о пространственно-временных границах произведения, специфике авторского хронотопа.

Цель статьи заключается в попытке выявить своеобразие авторского хронотопа в произведениях А. Жаксылыкова и Б. Каирбекова. В статье анализируются особенности хронотопа, характерные признаки его повествовательной структуры. Авторы статьи отмечают, что художественный хронотоп представляет собой сложную знаковую систему, состоящую из нескольких уровней и несущую в себе определенную информацию, которая раскрывается посредством кодов и лексикодов.

В результате анализа авторы формулируют выводы о том, что в эссеистике казахстанских русскоязычных писателей категория художественного хронотопа преАставляет собой «совокупность множественностей». В ее содержании сочетаются общечеловеческие, национальные, комлективные, частные концепции и теории времени-пространства. Авторы статьи утверждают, что в эссеистике Б. Каирбекова прослеживается явно выраженный этнокультурный характер образов и мотивов. Ключевые концепты и лексикоды произведений А. Жаксылыкова отражают бытовой уклаА Востока, являясь наиболее значимыми компонентами пространства и времени.
\end{abstract}

Кмючевые слова: эссе, хронотоп, мифотворчество, экспрессивность, концепт.

\section{Introduction}

In recent decades, there has been an increase in the interest of writers to "borderline" genres that combine the features of different styles. Essay is a genre that locates at the crossing of adjacent styles and combines their components. Concurrently, this genre cannot completely called neither scientific, nor journalistic, nor artistic. This poses the question about the content and formality of the genre, as about its functions. The insufficiently well-defined genre typology of the essay implies that its "borderline" forms can be appertain to this genre. The theme and subject matter of the essay give to it a common ground with scientific literature of a humanitarian nature, for instance, with philosophical tractates. In the essay, the author enunciates his philosophical reflections, the concepts about important parts of life. Signals of figurality and expressiveness, which afford an opportunity to the author to express feelings, move the essay closer to fiction. The way of problematic questions is put in an essay delivers the features of journalism.

The most important structure-forming principle of the essay is the leading role of the author's per- sonality, as it is from his position that the analysis of the idea of the creation is accomplish. Here, not only content, but also structural peculiarities are substantial. The singularity of the composition of the essay consists in the choice of two interlocutors in the capacity of the leading form of dialogue: the writer and the reader. The structure of the text is form up, as the author and his addressee seem to converge on the pages of the creation, hold out hands to each other, and be out for immediately find mutual understanding. The particularity of the poetics of the essay is reflected in the applying of mythological motives. The author in the writing theorizes his own views, creating a quaint myth, based on fictitious images. However, concurrently such a property of the essay is visible as the correlation with the present moment. The recited features of the essay were indicated in the works of philosophers, philologists, critics (Meletinsky: 1989; Epstein: 1989).

Thereupon, questions about such structural features of an essay as the arrangement of space and time, the author's notions about the time frames and boundaries of space, the typology of text componentry, their inter-linkages with artistic and figurative content demand to be heeded. The present article 
aims to justify the answers to the questions posed by identifying the individual author's chronotope in the creations of Kazakh Russian-speaking writers Aslan Zhaksylykov and Bakhyt Kairbekov, written in the form of essays.

\section{Literature review}

The term "artistic chronotope" was implement into the scientific terminology of M.M. Bakhtin. In his transactions, this phenomenon is regard as a complex system of elements and signs of several levels denoting certain information, which is unfold through lexical units, codes and lexicodes (Bemong, Borghart, De Dobbeleer, Demoen, De Temmerman, Keunen, 2010).

In contemporary literary criticism, the following forms of spatial and temporal boundaries of the text are lay emphasis:

1) the chronotope of cycles - what lies behind it is the idea of cyclicity, frequency, circulation of space and time. In the compound of a literary text, it looks like an archetypal situation, a priori formed from above, regardless of a person's will. Given type of space and time is oval, has no sharp corners, is similar to a circle and an ellipse. Spatio-temporal patterns of recurrence of natural cycles; the circulation of reality represents its symbolic load in the text of a work of art;

2) chronotope of a straight line - be backed by the chronological nature of phenomena, historicism of events, progressive process, movement from episodes of the past to the present day;

3 ) the chronotope of eternity - brings into being a special artistic world when space freezes and time stops. The singularity of this type is determined by the fact that all possible spaces exist in it simultaneously, and time is continuous and infinite;

4) the chronotope of nonlinearity - it contains the idea of multidimensionality. In it, the phenomena of rhythm and rhythm, tempo and temporality come to the fore. These units refer to the integral parameters of time and space of the text, and the terms are quite new. What do they mean? Temporality is understood as "the temporal essence of phenomena generated by the dynamics of their particular movement, in contrast to those temporal characteristics that are determined by the relation of the movement of a given phenomenon to historical, astronomical, biological, physical and other time coordinates" (Temirbolat, 2009).

Scholars contend that an objective chronotope has signs of time, including topological and metric properties. Qualities such as irreversibility, unidi- rectionality, discontinuity, and continuity compile topological properties. Duration or instantaneities are metric properties. If we discern the theory of the question, the most common concepts, then it should be stated that the objective chronotope includes two structures. Researchers formulate the following names: "past, present and future", or "earlier, simultaneously, later" (Ikonnikova, 2004; Leiderman, 2002).

There is also exist subjective time and space, based on a person and the outside world, the relationship between a person and the environment. We proceed from the premise that real phenomena and events are cognized by a person taking into account his life experience, moral views, moral ideals and value systems. The particularity of the social chronotope lies in a different framework. Researchers call this phenomenon the replenishment of public information, "the subject-practical preservation and transformation of the past." On the strength of this, it is thought that its parameters are unstable, transform, change. The conditions for these changes are events, processes occurring in society at different stages of evolution, comprehension and rethinking of historical facts of the past and present (Halpe, 2010; Hernandez, 2013).

The distinctness of the cultural and historical chronotope as a species is due to mythological motives; therefore, it is called the "mythopoetic chronotope". Researchers mean by the specific features of this type of time and space the following: a) the cluster and condensation of time, its transformation into a "fourth dimension"; b) the formation in its structure of intense properties, unfolding in the time frame of the myth; that is to say, the "temporalization" of space; c) the existence of a worldview complex expressed in a figurative form, which repels mythological ideas, moral values, traditions and beliefs shared by the bearers of a particular culture, as a result of which the chronotopic nature of the phenomena apparent in the mythopoetic consciousness of a person is created. (Ikonnikova, 2004; Agrell, Nilsson, 2003).

A scientific understanding of the categories of time and space claims an analysis of the content and structural features of a work of art. Inasmuch as it is only through them that space and time evince their role in the text, reveal their essence, which makes it possible to correctly interpret the processes of formation and contingence of space and time in the structure of the text. Contributors mark that the features of each text construct space by setting its boundaries, stage time frames, giving them significance in the text of a work of art" (Mahavidyalya, 2019). 


\section{Research results}

The analysis shows that in the essays of many Kazakh Russian-speaking writers, the cultural-historical and mythopoetic forms of the chronotopes prevail. The Russian-language nature of creativity is reflected in the peculiarities of poetics, including the originality of the author's chronotope. Let us turn to the work of the modern Kazakh writer Bakhyt Kairbekov.

Bakhyt Kairbekov's essay "Face of Time - Ray Movement" refers to the philosophical type of essay prose, devoted to the theme of Eternal Time, chronotopically built according to the principle of the "Circle", implying the eternal circulation in the world of nature and human life. The reflections of the poet-philosopher are refracted through the consciousness of the lyric hero - a nomad who has his own stable ideas about the phenomena called in the work "The Movement of the Ray, the Sun, and Nature". Compositionally, the author divides the text into six parts of different sizes, although there are three parts that are quite clearly distinguished in content, in which the images of the Past, Present and Future are consistently outlined (Kairbekov: 2008).

The clearly expressed ethno cultural character of the images and motives of Shanyrak and Yurt, Earth and Sky, Steppe and Path, Sun and Tree of Life allow the author to convey the philosophy of nomadism: "Penetration as the highest form of movement is the quality lost by Mankind! Penetration - wandering from one state to another! Hence - the variety of forms of Beating. The gaze is not set at a dead end, at a wall, at death and at the thought of death... The life of a nomad, as it was, remains unattractive. Nevertheless, his inner gaze was bright! The writer's inner monologue is centered around the key concepts that define the point of view of his nomad hero: The Essence of Nature is Movement, the first ray of the sun, falling on the hoop of the shanyrak, indicates Time. The sky for the nomad is the Father, the native Steppe is the Mother. In the movement of sand in the sand funnel lies the fragility of the world, but the eyes rest, observing the movement of nature. Man is the center of the Universe; his gaze is directed around, extended to all four cardinal directions.

The traditional confrontment of the main features of the eastern and western worlds leads to the author's generalizations: "That is why the hymns of the Turkic kagans began with the words: to the east - to the sea, to the west - to the high mountains, to the left of me - as far as the beast reaches, to the right of me - as far as the bird flies - to the foreseeable limits - I am the lord!" This is the Integrity of the Primordial World. Eternal companions warm the inner gaze of a nomad: this is a word, verse, music, kui, helping him to measure himself with boundless Principles, to perceive Space and Time. This is the spiritual world of a nomad, filled with a kind of harmony and philosophy that allows him to exist for centuries.

The world of modern man appears differently: "His house is conventional and pitiful. $\mathrm{He}$ is alone in the longing for the unrealizable. He is an orphan, excommunicated from Heaven and earth. He is excommunicated from songs, poems and fairy tales. His songs are faceless and dead. "This is the Present of a man of the 21 st century, who is longing for harmony, in nostalgia for the lost knowledge of Nature. But it is precisely in this melancholy and nostalgia that the poet sees hope, arguing that loneliness and helplessness can evoke courage and greatness. What needs to be done for this, how to live, how to act? How to return the blessing of the Earth and Heaven, remember your Path, rejoice over the first Ray of the Sun again? The author gives poetically inspired answers to the posed: "We have to raise Heaven - remember our sacred roots, return to our defiled Earth, drink plenty of spoiled water, and travel around many countries in our wanderings to make sure: we are of the same blood!" Then modern man will find his Tree of Life, his wheezing and whispering will turn into poems and songs, and the Future will find meaning.

Latent emotionality, at first glance, measured reflections, is conveyed not only through ethnonyms and sacred mythological images, but by syntactic figures of parallelism, stitching the entire text with a red line, for example: "Penetration as the highest type of movement ..., penetration is wandering from one state to another ... Father - my spirit ... Mother - my umbilical cord ... He is lonely ... He is excommunicated ... He is an orphan." This is how the rhythm of movement in a circle is created, symbolically indicated by the author: "Shanyrak is like a cart

wheel of the Sun ... The first ray, falling on the shanyrak hoop, slides over it, indicating the time to the nomad ..." A wheel, a hoop, a shanyrak, a sun, a circle - this is how the movement of Eternal Time is progressively transmitted, and the Past, Present and Future are nothing but points in this Movement of Space and Time (Kairbekov, 2008).

In the works of another Kazakh writer Aslan Zhaksylykov, the space-time structure of the texts is associated with the artistic idea of the works. The essay "The Enlightenment of Ahmed Yassawi" defines the cultural and historical type of chronotope, 
and it is associated with the image of the Bazaar as one of the key concepts of the world of the East, this is how it is described: "The ancient city of Yassy, one of a dozen of the same in the Otrar oasis: in the center is a citadel, a mosque, a madrasah, a vast bazaar square, several palaces, a rich quarter, a caravanserai at four entrances on four sides of the world, a gray scattering of shacks of the poor, artisans, other service people. In the daytime over the city, as always, the dense roar of camels, barking of dogs, yells of donkeys, the creak of a cart, a multilingual dialect and the hubbub of the bazaar crowd, at night - a huge universal moon over the minarets, an incessant boundless symphony of cicadas" (Zhaksylykov, 2003: 195).

The bazaar is one of the constituent parts of the eastern traditional city. Bazaars were not only a place of trade, but also the focus of social, political and cultural life - many important events took place there. Traditionally, the bazaar was located in the central square of the city, and this was due to archaic ideas about the bazaar as a symbol of the cosmic order and the equivalent of Peace, therefore the bazaar was given special cosmic significance in pre-Muslim and Muslim times both in Iran and in Central Asia. The death of the monarch in some traditional societies was perceived as cosmic chaos, as a result of which the bazaars were immediately destroyed. It is known that there were two bazaars with mosques in Bukhara. It should be noted that the location of the markets in the city center and the location of the kings on the territory of the market or in the immediate vicinity of it were typical for the entire Islamic world. Moreover, each of the three constituent parts of the urban space in the Muslim world acquired its own symbolic meaning. The palace (or residence) of the ruler was likened to the lungs of the city body, the mosque to his heart, and the market was compared to the organs of food.

The Enlightenment of Ahmed Yassawi reflects the attitude to the bazaar as a cosmic symbol of the eastern world: "The market square is the main goal of the boys' travel. The bazaar is an embodied world, a universe that has roamed to you. Infinity, mystery was embodied in a noisy multilingual crowd, in an oceanic bustle, cries that amaze the ear, in the overflow of faces, as if carried by one force, in a heated argument and excitement of eyes climbing out of the sockets of the eyes, in the glitter, multicolored radiance of objects and goods from various countries and even from other worlds. Bazaar! "(Zhaksylykov, 2003: 197).

It is no coincidence, in our opinion, that the meeting of the unknown boy Akhmed with the teacher takes place in the central square of the city. This meeting is presented as fateful, it is no mere chance that there are images of a minaret and a mosque, which suddenly pass into a tall man with burning piercing eyes. It seems to the boy that time has evanished, and he and this man are left alone, beyond of the crowd, the noisy market square. This is how Ahmed's meeting with his teacher, Sheikh Arstan Baba, is depicted. Beneath our eyes, time and space are shifting, Ahmed detaches from the general market crowd, a symbolic separation of the future saint from the worldly vanity takes place, and he embarks on the course of enlightenment. Here the space of the bazaar embodies the weakness of a person, gluttony, on the contrary, the word picture and space of the mosque is spirituality and piety.

It is noteworthy that the image of Bazar and its chronotopic properties are described not only in essays, but also in the novels of Zhaksylykov. For example, another, modern oriental bazaar is found in the novel Singing Stones. The protagonist of this novel, also an intellectual who failed to adapt to the changes taking place in the country, flees the city and falls into voluntary slavery to an old Chinese. It is paradoxical that he is quite happy in this new position; he does not have to think about the meaning of life, to reflect, because now the master must think about his slave. One day, an enterprising Chinese man goes with his newly minted slave to the bazaar to sell manti.

In the description of this bazaar there is no longer any spirituality: "The armies, hordes, friendly legions passed, marched, wedged in, took with an attack dill, celery, watermelon, tomato, meat rows, leaving crushed crusts, bones, seeds, shells to death, marched on, innumerable, unstoppable in a fierce thirst to take, grab, absorb and snatch again. It was a peaceful battle of the parties striving for mutual satisfaction in the name of the triumph and jubilation of life." It reflects the new realities of the time, new market relations, where the main thing is profit and competition: "The place where we settled down was in the very center of the flea market. The human sea of variegated lava flowed around us with a dull underground rumble. A burly, mustached Uyghur woman next to us went into a commercial rage, incessantly shouting: "Peaches! Peaches! Delicious, good, sweet peaches! She smiled sickly at the crowd, managing to shoot us sidelong hostile glances. We were undesirable impudent competitors for her" (Zhaksylykov, 2003:159).

The bazaar, which at first introduces the protagonist into euphoria and is perceived as a celebration of life, instantly transforms into another trap: "A 
strong push in the back, and I found myself on the ground with raised legs and absurdly outstretched arms. The Uyghur woman proudly stood on her hips and triumphantly towered over me. Her sharp heart-rending cry drowned out the noise of the bazaar: "Thief! I caught a thief!! Look at this jackal! He stole my money! Unfortunate drunkard! Wow, for the shaitans to tear you apart! » The old Chinese man immediately disappears without a trace, a policeman comes to the call of the crowd, in whom a former intellectual, and now a typical homeless person, recognizes his college friend named Bayan: "The color of confusion and intense embarrassment rushed into his face, and I clearly saw in his stunned eyes the question: ""You? .Really? Is that you?.." At the moment when our eyes met, time stopped ... Bayan's pupils, melancholy, motionless, blindly looked at me, as ifrefusing to admit the obvious. The lips tensed, trembled, preparing to pronounce the name..." (Zhaksylykov, 2003: 59).

This is how the protagonist meets his past; it is here in the bazaar that the realization comes to him that he is at the very bottom of the social ladder. He thinks about what he has done with his life, recalls what brilliant hopes he showed in his youth, at the time of friendship with Bayan...Here the bazaar acts as a mirror reflecting society, indicating its ugly change. Thus, we can conclude that Aslan Zhaksylykov's bazaar acts not only as a symbol of cosmic harmony, but also as a kind of economic and social barometer. In the East, bazaars have played and continue to play not unimportant part. The bazaar is an intrinsic part of any eastern city, the bazaar is eternal.

\section{Conclusion}

Recapitulations on the topic of this article are established on our understanding of time-space as a special artistic system and structure. The conducted analytical work and reliance on the convictions of scientists induce to believe that this category involves historical, cultural, philosophical and aesthetic, religious and mythological, geographical componentries. The recited componentries are construed by us as cultural and historical codes that determine the originality of the author's time-space, imaging the relationship between the content and structure of the text, arranging for the signs of the chronotope into a system, particularizing its role and significance in the text, based on the ideological concept of a literary work, world- view and values writers' orientations. The article ascertains that the historical code characterizes the era depicted by the author and expresses the position of the writer toward to the spatio-temporal organization of his work (Sabitov, 2004; Kroll, Bobb, Hoshino, 2014).

The national reflecting of the writer, his mentality are come true in the time-space of the text by means of a culturological code. Here, such level of details as mental traditions, everyday realities, cultural values of the people, and the construct of the world around that has developed over the centuries, the concept of a person, his convictions about the past and the present are meaning a lot.

Alternate methods of organizing time-space fulfill other functions, for instance, the philosophical and aesthetic code helps to ascertain the ideals and moral and ethical values of the author-creator. The religious and mythological code reflects information on the topic of eternal time, the cyclical nature of events, the frequency of life phenomena. The religious and mythological element broadens the spatial and temporal boundaries in the structure of the literary text. There is also a geographic code that enters an element of chronology, elaborates information about what kind of time and space is described in the writing. Owing to the geographic code, the represented events gain clear and definite space-time coordinates. The analysis revealed that the components of the text structure studied by us are not only related to each other, but also essentially furnish out each other. For a total, they make a single semantic and compositional unity, reflecting the writer's artistic world and the particularities of his chronotopic notions.

As follows from the analysis of the material under study, it was concluded that in the works of Kazakh Russian-speaking writers written in the essay genre, the category of time-space is rigorously formed and represents a unified whole, or, as they say, "a set of pluralities". Concurrently, the authors unite in their works universal, national, collective, private and their own concepts of time-space. Thus, in B. Kairbekov's essays, a clearly expressed ethno cultural character of images and motives can be traced: Shanyrak and Yurt, Earth and Sky, Steppe and Path, Sun and Tree of Life allow the author to convey the philosophy of nomadism. The all-encompassing gaze of the writer - a modern person striving to unite the past, present and future determine the specificity of the chronotope in his consciousness. 
In the compound of the time-space of the text, different lexical units and lexicodes are embossed, which are antonymic pairs, for example: individual and collective; real and imaginary, linear and oneiric; transitory and eternal. Lexical units come with ascertainable semantics and become, in the associative minds of readers, a semantic code for the concept of a creation. Worth recalling in this regard is about definition of Umberto Eco, who named this phenomenal occurrence so "the second connotation".
The key concept and lexicode "Bazaar" as an integral component of the everyday life of the East is present in the works of A. Zhaksylykov, being an important part of the chronotope. It represents the center where the individual chronotopes of people intersect. The bazaar is the embodiment of a combination of languages and cultures. Its visitors and inhabitants are people of different nationalities and from different social strata of society. Accordingly, cultural-historical, social, psychological chronotopes are connected at its level.

\section{References}

Agrell B., Nilsson I. "Introduction" to Genres and Their Problems: Theoretical and Historical Perspectives// Genres and Their Problems: Theoretical and Historical Perspectives. - Gothenburg: Daidalos, 2003. - pp. 9-25.

Bemong N., Borghart P., De Dobbeleer M., Demoen K., De Temmerman K., Keunen B. Bakhtin's Theory of the Literary Chronotope: Reflections, Applications, Perspectives. - Gent, Belgium: Academia Press, 2010. - p. 213.

Epshtein M.N. (1989). Na perekrestke obraza I poniyatiya (esseizm v culture novogo vremeni). M.N.Epshtein., Paradoksy novizny. O literaturnom razvitii XIX-XX vekov. [At the crossroads of an image and a concept (essayism in the culture of modern times). M.N. Epstein. The paradoxes of novelty. On the literary development of the XIX-XX centuries]. - Moscow: Soviet writer.

Halpe A. Between Myth and Meaning: The Function of Myth in Four Postcolonial Novels. - University of Toronto, 2010.

Hernandez, A.E. The bilingual brain. - Oxford: Oxford University Press, 2013.

Иконникова С.Н. Хронотоп культуры как основа диалога поколений // Очерки: сборник научных трудов - СПб: СанктПетербургское философское общество, 2001. - С. 69-74.

Каирбеков Б.Г. Части целого. Стихи, проза. - Алматы: Атамура, 2008.

Kroll, J., Bobb, S., \& Hoshino, N. Two languages in mind: Bilingualism as a tool to investigate language, cognition, and the brain. Current Directions in Psychological Science. - 2014.

Leiderman N.L. To save literature, save yourself with literature//The world of the Russian word. - M., 2002. - No. 3 (11). - P. 58-66.

Mahavidyalya M. The Relationship between Mythology and Literature// Journal of Advances and Scholarly Researches in Allied Education. - Narwana: Ignited Minds Journals, 2019. - p. 1149 - 1155.

Мелетинский Е.М. Мифологический словарь. - М.: Советская энциклопедия, 1991.

Robert M.S. The Bilingual World: a study on bilingualism and its cognitive effects. - Barcelona: Curs, 2017. 81-89.

Сабитов А. Пространственные представления в казахстанском актуальном искусстве // Евразия. - 2004. - № 1. - С. 2009.

Темирболат А.Б. Категория хронотопа и темпорального ритма в литературе//Монография. - Алматы: Ценные бумаги,

Жаксылыков А.Ж. Просветление Ахмеда Яссави // Тан Шолпан, 2003. - №5. - С.195.

\section{References}

Agrell B., Nilsson I. (2003). "Introduction" to Genres and Their Problems: Theoretical and Historical Perspectives// Genres and Their Problems: Theoretical and Historical Perspectives. - Gothenburg: Daidalos. (in English)

Bemong N., Borghart P., De Dobbeleer M., Demoen K., De Temmerman K., Keunen B. (2010). Bakhtin's Theory of the Literary Chronotope: Reflections, Applications, Perspectives. - Gent, Belgium: Academia Press. (in English)

Epshtein M.N. (1989). Na perekrestke obraza I poniyatiya (esseizm v culture novogo vremeni). M.N.Epshtein., Paradoksy novizny. O literaturnom razvitii XIX-XX vekov. [At the crossroads of an image and a concept (essayism in the culture of modern times). M.N. Epstein. The paradoxes of novelty. On the literary development of the XIX-XX centuries]. - Moscow: Soviet writer. (in Russian)

Halpe A. (2010). Between Myth and Meaning: The Function of Myth in Four Postcolonial Novels. - University of Toronto. (in English)

Hernandez, A.E. (2013). The bilingual brain. - Oxford: Oxford University Press. (in English)

Ikonnikova S.N. (2001). Khronotop kultury kak osnova dialoga pokoleniy. Ocherki: sbornik nauchnyh trudov. [Chronotope of culture as the basis of the dialogue of generations. Essays: collection of scientific works]. - St. Petersburg: St. Petersburg Philosophical Society. (in Russian) 
Kairbekov B.G. (2008). Chasti tselogo. Stikhi I proza. [Parts of the whole. Poetry and prose]. - Almaty: Atamura (in Russian) Kroll, J., Bobb, S., \& Hoshino, N. (2014). Two languages in mind: Bilingualism as a tool to investigate language, cognition, and the brain. Current Directions in Psychological Science. (in English)

Leiderman N.L. (2002). To save literature, save yourself with literature// The world of the Russian word. - M. (in English)

Mahavidyalya M. (2019). The Relationship between Mythology and Literature// Journal of Advances and Scholarly Researches in Allied Education. - Narwana: Ignited Minds Journals. (in English)

Meletinskiy E.M. (1991). Mifologicheskiy slovar. [Mythological dictionary]. - Moscow: Soviet encyclopedia. (in Russian)

Robert M.S. (2017). The Bilingual World: a study on bilingualism and its cognitive effects. - Barcelona: Curs. (in English)

Sabitov A. (2004). Prostranstvennyie predstavleniya v kazakhstanskom aktualnom iskustve. [Spatial representations in contemporary Kazakhstan art]. - Eurasia. (in Russian)

Temirbolat A.B. (2009). Kategoriya khronotopa I temporalnogo ritma v literature. Monografia. [The category of chronotope and temporal rhythm in the literature. Monograph]. - Almaty: Security papers. (in Russian)

Zhaksylykov A.Zh. (2003). Prosvetlenie Akhmeda Yassawi. [The Enlightenment of Akhmed Yassawi]. - Tan Sholpan. (in Russian) 